\title{
Editorial
}

\section{Divulgar conhecimento é fundamental}

Escrever o editorial deste número da revista Fisioterapia em Movimento foi uma tarefa especialmente gratificante e, ao mesmo tempo, de imensa responsabilidade.

A gratificação está relacionada ao fato de comprovar, por meio da diversidade dos artigos apresentados, que a missão do periódico faz-se em ato. O conteúdo dos manuscritos leva o leitor a conhecimentos distintos: uma imersão em duas realidades de projetos político-pedagógicos de cursos de Fisioterapia, um pautado na construção coletiva de seus eixos e outro concentrado no dueto funcionalidade humana e Sistema Único Saúde (SUS); revisões de literatura que abordam ciclos de vida, inserindo a problemática da osteoporose em idosos, a alteração de aparelho locomotor em crianças e adolescentes, e o domínio de programas de reabilitação em portadores de AVE; o relato de experiência da atuação da Fisioterapia no âmbito da Saúde da Família; os resultados de pesquisas descritivas e analíticas direcionadas à prescrição de exercícios aquáticos; o condicionamento respiratório de portadores de paralisia cerebral; a morfologia de pés e joelhos no equilíbrio; o uso de instrumentos na manovacuometria; o equilíbrio de atletas de futsal; a Distrofia de Duchenne; a Síndrome de Down; e a influência de fatores ambientais no controle cervical de lactentes nascidos pré-termo.

O outro aspecto, a responsabilidade, refere-se à incumbência de dividir com os leitores a notícia da inserção da revista Fisioterapia em Movimento no sistema SciELO (Scientific Electronic Library Online), juntando-se aos mais de 630 periódicos da rede. Esse fato é a resposta à política de qualidade que a revista conduz nestes mais de 21 anos de produção, cuja credibilidade determinará um incremento de acessos aos artigos publicados e, consequentemente, à melhoria de seu fator de impacto.

Fazer parte da rede SciELO é resultante de um sério processo de avaliação, cujos procedimentos de admissão compreendem os aspectos de formato (adequação às normas), de endogenia (relação entre a concentração institucional e geográfica do conselho editorial e dos autores) e de conteúdo (qualidade dos manuscritos).

Como se percebe, os afazeres são distribuídos coletivamente: aos autores, o encaminhamento de artigos de qualidade; aos revisores, a garantia desta qualidade e o cumprimento de prazos de revisão; e à administração da revista, a pontualidade e o respeito às normas.

Dessa forma, cumpre-se o aspecto fundamental da missão da revista, que é "constituir-se em estímulo e instrumento de divulgação dos resultados da investigação científica".

À revista, meus parabéns!

A todos nós, boa leitura e bom trabalho!

Profa. Dra. Marcia Regina Cubas

Programa de Pós-graduação em Tecnologia em Saúde Pontifícia Universidade Católica do Paraná 